\title{
Contested Ideologies of Space in Hispanic American Cartographic Practices: From the Abstract to the Real in Spanish and Indigenous Maps of Yucatán
}

\section{Cody Barteet}

Volume 38, numéro 2, 2013

Contemporary Scholarship on Latin American Art

Approches contemporaines de l'art latino-américain

URI : https://id.erudit.org/iderudit/1020792ar

DOI : https://doi.org/10.7202/1020792ar

Aller au sommaire du numéro

Éditeur(s)

UAAC-AAUC (University Art Association of Canada | Association d'art des universités du Canada)

ISSN

0315-9906 (imprimé)

1981-4778 (numérique)

Découvrir la revue

Citer cet article

Barteet, C. (2013). Contested Ideologies of Space in Hispanic American Cartographic Practices: From the Abstract to the Real in Spanish and Indigenous Maps of Yucatán. RACAR : Revue d'art canadienne / Canadian Art Review, 38(2), 22-39. https://doi.org/10.7202/1020792ar

\section{Résumé de l'article}

Cet article examine la " construction » de l'Amérique hispanique par les cartographes du XVI ${ }^{\mathrm{e}}$ et du XVII ${ }^{\mathrm{e}}$ siècle. À travers une étude d'objets cartographiques créés pour la monarchie espagnole, nous analysons les représentations divergentes faites par les Mayas du Yucatán et par d'autres autochtones de l'Amérique. Ces objets reflètent l'hétérogénéité de leurs créateurs dont les diverses motivations (politiques, juridiques et économiques) ne correspondent pas toujours aux intérêts du roi. Puisant dans la tradition cartographique de l'Amérique hispanique ainsi que dans les théories actuelles concernant les pratiques cartographiques, nous démontrons que les cartes participent à la formation de la culture hispano-américaine et soulignons l'évolution de la carte comme forme abstraite.
Tous droits réservés (C) UAAC-AAUC (University Art Association of Canada | Association d'art des universités du Canada), 2013
Ce document est protégé par la loi sur le droit d'auteur. L'utilisation des services d'Érudit (y compris la reproduction) est assujettie à sa politique d'utilisation que vous pouvez consulter en ligne. 


\title{
Contested Ideologies of Space in Hispanic American Cartographic Practices: From the Abstract to the Real in Spanish and Indigenous Maps of Yucatán
}

\author{
Cody Barteet, The University of Western Ontario
}

\begin{abstract}
Résumé
Cet article examine la « construction » de l'Amérique hispanique par les cartographes du XVle et du XVIle siècle. À travers une étude d'objets cartographiques créés pour la monarchie espagnole, nous analysons les représentations divergentes faites par les Mayas du Yucatán et par d'autres autochtones de l'Amérique. Ces objets reflètent l'hétérogénéité de leurs créateurs dont les diverses motivations (politiques, juridiques et économiques) ne correspondent pas toujours aux intérêts du roi. Puisant dans la tradition cartographique de l'Amérique hispanique ainsi que dans les théories actuelles concernant les pratiques cartographiques, nous démontrons que les cartes participent à la formation de la culture hispano-américaine et soulignons l'évolution de la carte comme forme abstraite.
\end{abstract}

$\mathrm{I}_{\mathrm{n}}$ 1556 Philip II ascended the Spanish throne. As the son of Charles V, Holy Roman Emperor and King of Spain, and the grandson of the Catholic monarchs Isabella and Ferdinand, Philip inherited one of the largest empires in history. Over the next forty years, he expanded his territories and engaged in an ambitious campaign to document its ever-increasing boundaries. For visual representations of his empire, he turned to the science of cartography. Philip seemingly understood the implicit value of cartographic objects as apparatuses to govern and control spaces. He charged his royal cosmographer, Juan López de Velasco, with mapping and documenting the entire Spanish empire, both domestically and abroad. ${ }^{1}$ Velasco and the court developed strategies that blended text and image. Among them are the multi-page relaciones (accounts), answers to a series of instrucciones (instructions) - a list of fifty questions regarding a territory's history, its resources, its ecology, and its peoples- that colonial subjects were mandated to complete. The responses to three of the questions were to include maps of the polities. To fulfill the requirements of the instrucciones, the artistically inexperienced conquistadores and settlers relied on Indigenous artisans. ${ }^{2}$ The cartographic or landscape images are known as the relaciones geográficas (geographic accounts). ${ }^{3}$ In these visual productions, a subtle merging of text and image occurs: the pictorial representations are sometimes accompanied by inscriptions, as we see in the 1581 map of the guardianship of Motul, Yucatán (fig. 1).

This image-part of what is known today as Relaciones de Yucatán (Accounts of the Yucatán), the Yucatecan responses to the monarchical inquiry-replicates the new power structures that existed in sixteenth-century Yucatán. Though simple in execution, the Motul drawing is an important part of the Relaciones de Yucatán, for it is one of only three responses that contain a pictorial element. In the image, as in the text that accompanies it, the guardianship's towns are recorded in relation to Mérida, the peninsular capital and centre of power. ${ }^{4}$ The Motul account does not simply situate the town in relation to Mérida-a distance of some 43.1 kilometres (26.7 miles) — visually, it also identifies its proximity to the capital in the written narrative that likewise records the history of the town's people, its geography, and the ecology of its hinterlands. The Spaniard Martín de Palomar, who was charged with completing the Motul inquiry, enlisted the help of Maya scribes Juan Peche and Juan Cumci de Landa to produce the Motul account. It is likely that either Peche or Cumci de Landa produced the drawing, in part because of the similarity between the script in the image and its accompanying relación. An even more compelling argument for Maya attribution is the map's eastern direction, a common Indigenous practice; by the sixteenth century, European maps favoured a northern orientation, and question 10 of the instrucciones specifically required referencing the northern and southern directions. ${ }^{5}$ The text and image of this map attempt to make real the conceptual idea of Motul and its guardianship by blending text and image to create an abstract signifier of the province in both Spanish and Maya terms.

The practice of recording local histories was widespread among the pre-contact Maya peoples. Peche's and Cumci de Landa's responses were probably derived from Maya books of the chilam balam, texts written for and by Indigenous nobles at various historical moments. They contain extensive historical, mythological, prophetic, calendrical, and medicinal information that is divided into sections or volumes. ${ }^{6}$ Much of this data was translated and used to respond to the royal inquiry, thus perpetuating the long Maya tradition of historical transcription. What is more, pre-contact Maya and their Mesoamerican counterparts produced cartographic imagery to document territories. 7 This ancient Maya practice, which continued well into the colonial era, can be see in some of the Yucatecan chilam balam, which contain cartographic objects that display distinctive and primarily Indigenous sensibilities. Some scholars question the popularity of pre-contact mapmaking processes in Yucatán because of the lack of surviving examples, which is partly due to the destruction of many of these objects during well-documented Franciscan idolatry 
campaigns. ${ }^{8}$ Nevertheless, the Yucatecan Maya did produce astoundingly complex cartographic objects during the colonial era. This suggests they understood how maps could document lands in abstract terms and were familiar with the use of both text and pictographs to do so. The Motul map and its accompanying relación, then, illustrate the complex multicultural negotiations transpiring between text and image in the sixteenth century.

The early colonial era witnessed European and Indigenous efforts to define the new global world: in the sixteenth century the concepts of Hispanic and Latin America were not fully constituted in the public discourse. ${ }^{9}$ Seemingly, both European and Indigenous peoples understood the map's potential for replicating authority. The Motul map indicates how the Maya understood the town's standing in regard to its guardianship and to the colonial capital. Although subject to Mérida, Motul exercised authority over a region. For power to be validated over lands (by either Maya or Spanish peoples), the territory must be created. In other words, space must be produced, to borrow Henri Lefebvre's terms, through conceptual and physical exercises, which the Motul image does. ${ }^{10}$

This paper examines the processes through which early modern cartographers created conflicting spaces of Hispanic America. Though the maps produced for Philip II serve as the basis for this study, they are only a small fraction of the hundreds - if not thousands — of maps created during the colonial period. I therefore reference and discuss numerous other cartographs made for judicial proceedings as well as those executed for popular cultural texts. With this broader context of American cartographic practices in mind, I focus on several extant maps from colonial Yucatán, many of which were produced by Indigenous peoples. The Yucatec cartographs are only a few of the hundreds that were created through the entire colonial era by numerous Amerindians who were distinct from each other ethnically, economically, geographically, temporally, and so on. Not surprisingly then, these cartographic documents highlight their creators' heterogeneity, many of whom had economic, judicial, and political motivations that did not always correspond to royal interests. Nevertheless, these images contributed to the production of Hispanic America. In other words, the cartographs fulfilled ideological functions for the heterogeneous colonial peoples. The diversity in the form and content of the maps thus reflects social, political, economic, and other cultural desires, while simultaneously fostering new forms of knowledge through the merging of culturally distinct and previously separated peoples, all practices that developed in Yucatán.

To understand this diversity, I first contextualize the study of cartography in Hispanic American studies. I focus primarily on what can be defined as the ideology of the European-derived map, in which the grid form played a critical role in docu-

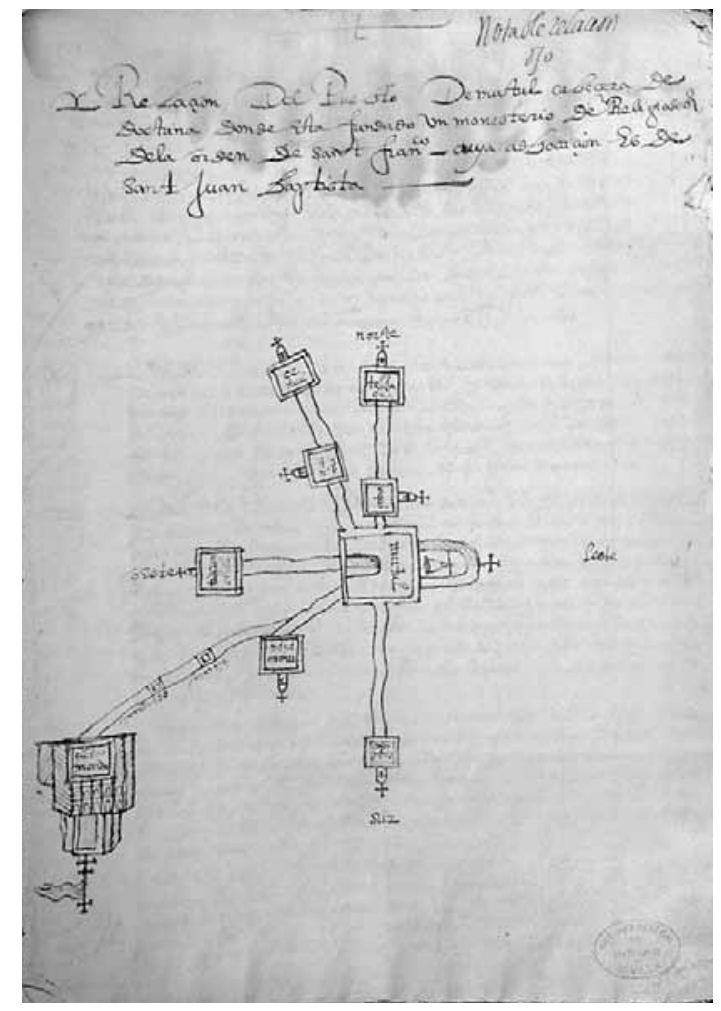

Figure I. Anonymous, Map of Motul (Yucatán), I58I. Ink on paper, $20 \times 15 \mathrm{~cm}$. Seville: Archivo General de Indias (photo courtesy of Archivo General de Indias).

menting the lands, resources, cities, and peoples of the Americas. But the grid was not the only formula used to construct maps. In certain instances the overriding contextual structures of the grid limited the Indigenous peoples in their engagements with the new colonial society, while in others the aboriginal artists were able to produce powerful multivocal images of Indigenous agency and political activism. I argue that cartography and mapmaking practices offer an important glimpse into the formation of Hispanic American culture as well as into the evolution of the map as an abstract form.

\section{The Ideology of Empire}

Philip II's recognition of the potential power of maps for governing does not seem to have been inherited by his successors; nor were the maps and cartographs he commissioned reproduced en masse. Only a few of the hundreds of Iberian cartographs produced for Philip II made it out of the Spanish realms to serve political and scientific ends. ${ }^{11}$ Nevertheless, in the last few decades, the study of cartography has played an important role in a discourse on Latin American history that recognizes 
maps as, in the words of prominent geographer J. B. Harley, "refracted images of the socially-constructed world" that represent "embedded social visions." 12 With this in mind, scholars often approach the cartograph from one of the following perspectives: European mapmaking processes; Indigenous mapping practices; or the hybrid mapmaking practices and cartographic forms that emerged from the collision of these cultures. More recent discussions have analyzed maps in relation to theories pertaining to post-colonial Latin American identity formation. ${ }^{13}$ Much of the discourse is tied explicitly to Iberian maps, and how they represent negotiations of space and emerging scientific technologies. Maps also frequently render their content in European cultural terms. Focusing on this latter aspect of cartography, many academic studies have concentrated on the ideological purposes of the maps and landscape imagery created primarily by the Iberians and other Europeans. Imperative to these discussions is the application of the Renaissance grid, which was developed through revitalizations of ancient Roman architectural treatises and early modern scientific advancements in linear perspective techniques. Many scholars have considered the grid's development to be connected to abstract ideas about power relationships. ${ }^{14}$ These power constructs are rooted in the grid's operational value as a compartmentalizing device. It is a compositional design that imposes narrative frameworks, allowing for the conceptualization of hierarchies and distinctions among objects, peoples, and so on. For example, the grid was commonly used as the compositional structure to depict the racially charged cuadros de castas (casta paintings). 15 For the Mexican colonial elite who most likely commissioned these paintings, the grid visually stabilized racial, ethnic, and even social norms: the various racial mixtures - consisting of a woman and a man of the same or different races and their progeny-are confined within the grid's individual cells, each numbered in sequential order and with accompanying taxonomic, identifying captions. It is through the structure established by the grid that the Hispanic American peoples are seen by the colonizing elite.

For Walter Mignolo, the processes that created the gridded map assisted in the deterritorialization of Indigenous peoples, because the grid's science and history is ingrained in European rather than Indigenous American traditions. Mignolo contends that the Western scientific map denied native peoples the ability to manipulate space, as it forced them to create space within European constructs. ${ }^{16}$ The privileging of the European grid thereby enabled European and Hispanic American intellectuals to cultivate their claims of cultural, political, economic, and religious dominance over Indigenous peoples. While these ideas are open to question, as we will see below, privileged Western knowledge systems did manifest themselves in various ways throughout the colonial and post-colonial eras.
The grid as a product of power relations is exemplified in Willem Janszoon Blaeu's 1642 Americe Nova Tabula (fig. 2).17 Here, the grid operates on many levels. First, it formalizes the longitudinal and latitudinal variants, while also framing and ordering the taxonomic representations of several checkerboard gridded-style towns, including Mexico City, Cuzco, Santo Domingo, and Cartagena. Second, the Indigenous peoples are removed to the margins, where they are rendered as caricatures. This image virtually codifies the grid's ability to document lands and to promote ideology through the implied physical, conceptual, and social ordering of lands and cities that further establishes orientation and human classification.

Images such as Blaeu's have fueled Mignolo's postcolonial analyses. Mignolo contends that by the end of the colonial era, the modern idea of Latin America was beginning to take shape. Much of his argument rests on the supposed inherent clarity of historical maps: he describes maps as simultaneously real and not real, i.e., conflating the physical and conceptual ideas about that place. According to Mignolo, we often accept cartographic images as being the real territory they abstractly represent. In this way, maps create the world. Such theoretical precepts are common, and many theorists have relied on maps to understand our world. Jean Bauldrillard states, "The territory no longer precedes the map, nor survives it. Henceforth, it is the map that precedes the territory... [and] it is the map that engenders the territory." 18 Therefore, maps influence our perceptions of the physical world and of the societies that inhabited it. Mignolo concludes that Latin America-because of its actual location and of its depiction in maps-remains on the margins of the West and the United States. 19

However, such assessments are overly concerned with cultural constructs and not enough with the physical environments in which American peoples lived. For example, Blaeu's image also conveys the effectiveness of urban practices that helped establish the Spanish colonial physical ordering on American frontiers. Many representations of American urban centres, for instance those of Cuzco and Mexico City, which are based on the Italian Giovanni Battista Ramusio's late sixteenth-century prints, slavishly adhere to a grid plan (figs. 3 and 4). ${ }^{20}$ In their original form, as prominent historian Richard Kagan suggests, the contrast in the cityscapes between the rigidly defined urban centres and the fictive, imagined landscapes fostered the civic and communal identities of the Spanish urbs or cultural centres. ${ }^{21}$ The Spanish cities are juxtaposed with the monte (mountains or scrublands), the unsettled and un-Christianized lands where, as the governor of Yucatán don Francisco de Solís informed Philip II in 1584, the Maya "worship idols" and resist Spanish acculturation practices. ${ }^{22}$ Such comments demarcate locations with a clearly defined European presence from those beyond the grid-planned cities. The images reveal the grid's 
BARTEET | Contested Ideologies of Space in Hispanic American Cartographic Practices

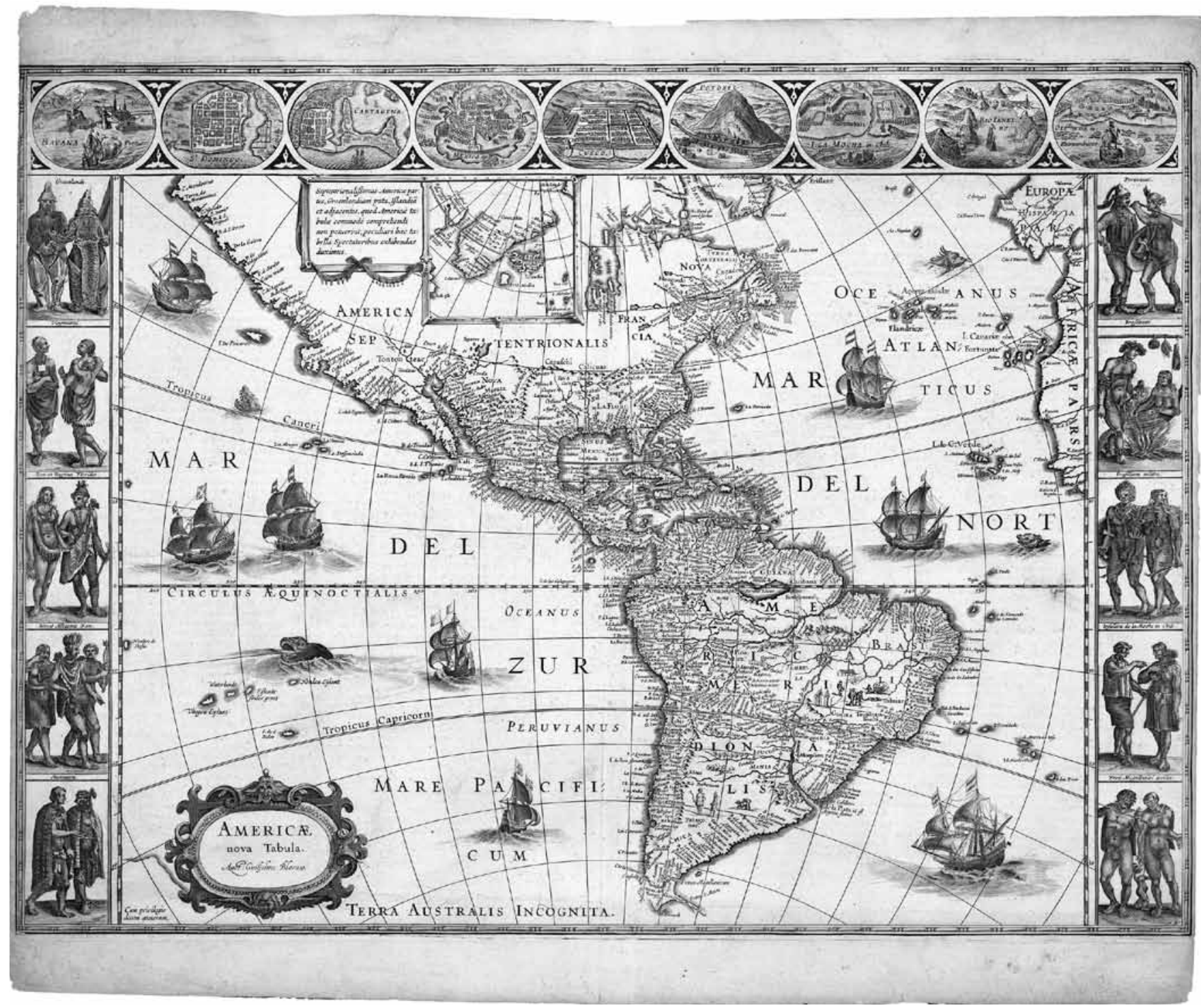

Figure 2. Willem Janszoon Blaeu, Americæ Nova Tablua. From Theatrum orbis sive Atlas novus, vol. II (Amsterdam, 1642$)$. Engraving, $36 \times 46 \mathrm{~cm}$ (photo courtesy of Folger Shakespeare Library, Washington, DC).

literal, lived form-the damero, or European-conceived checkerboard-gridded city. Like the related cartograph, the urban grid reflects the desire to promote the ordering of society through socially and physically defined spaces. These spaces are explained in the Ordenanzas de Población (Settlement Ordinances) included in the 1573 Las leyes de Indias (Laws of the Indies) compiled for Philip II. ${ }^{23}$ The policies describe the general logic, order, and structure of newly founded Hispanic American cities. The ordinances implicitly delineate urban space using a grid or orthogonal plan (traza en damero), in which government and religious buildings are situated around the heart of His- panic American cities: the plaza mayor. These ordering practices produced space and its social hierarchies. As Henri Lefebvre rightly suggests,

The result [of town planning] is a strictly hierarchical organization of space, a gradual progression outwards from the town's centre, beginning with the ciudad [capital/major city] and reaching out to the surrounding pueblos [small towns/ villages]. The plan is followed with geometrical precision; from the inevitable Plaza Mayor a grid extends indefinitely in every direction. 24 


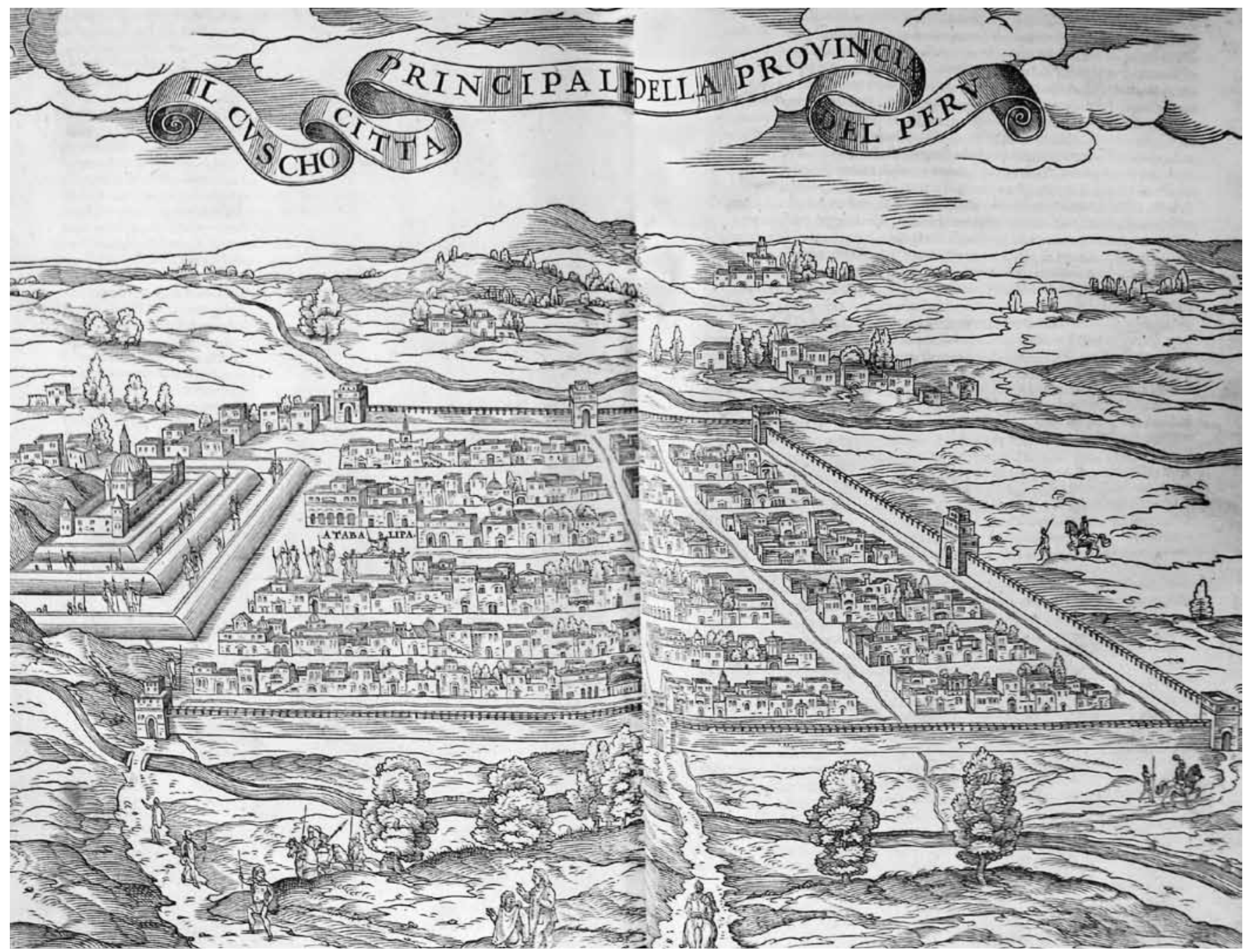

Figure 3. Giovanni Battista Ramusio, II Cuscho Citta della Provnicai del Peru. From Viaggi et Navegatinoi, vol. III (Venice, I556). Engraving, height: 33 cm (photo courtesy of The University of Western Ontario Libraries, London, Ontario).

Thus, as Lefebvre posits, the monarchy strove to create a space that was quantifiable and distinguishable through regularized legislation, visual reproductions, and the literal erection of towns. Such constructions established a contrast between the clearly marked spaces of the Spanish urbs and the less defined spaces of the monte.

These significant social facets of Hispanic urbanism were not lost on the conquistadores and European intellectuals. The latter learned of these urban practices through images like those of Cuzco and Mexico City, which were widely reproduced from Ramusio's prints. Kagan analyzes these reproductions of Ramusio's prints and others like them in negative terms, arguing that they construct conceptions of the Hispanic domains as unchanging, prefiguring the modern abstraction of Latin America. 25
Nonetheless, the prints make manifest the implementation of urban polices that tried to mitigate cultural instability. These policies established a regularized landscape created through the grid that also signified social, religious, and political hierarchies, an urban structuring that was difficult to obtain in Old World centres.

Acknowledgment of the grid's "authority," in both its urban and conceptual forms, is found in the 1581 map of Cholula in Puebla, Mexico (fig. 5). ${ }^{26}$ The image was created for the relaciones geográficas, most likely by a Mixtec artisan; it contains many non-European features, such as Indigenous script and iconography, within the compositional design of the grid. ${ }^{27}$ From the recording of habitats to the marking of sacred, hybridized Mesoamerican-Christian temples, all features are made to 
conform to the European grid, restricted to their appropriate cell or solar (urban block) of the town's traza. The grid contains pre-existing Indigenous history by confining it to its cell, or past moment. Conceptually, then, the image operates within the discourse of the deterritorialization of Indigenous peoples, and the Pre-Columbian cultural traditions are symbolically denied any historical significance. The Indigenous centre has been reconceptualized through the rendering of the clearly demarcated buildings and churches: churches replace the altepetl (water hill) used in Mesoamerican pictographic traditions to mark pyramids and to recall associated communal narratives about time, place, and people. ${ }^{28}$ The celebrated markers of preColumbian communal identity - the pyramids-are replaced by churches, the civic symbols of many European towns. ${ }^{29}$ The churches and the grid serve to neutralize an existing Indigenous past.

The map can be understood as an example of Spanish institutional control, its primary purpose to exert the monarch's power over the peoples and the physical and conceptual spaces of the Americas. 30 This brings to mind George Simmel's discussion of the interrelationships within maps. He argues that the forms and contents within space(s) interact:

The extent to which space, as land for example, can be framed or bounded is significant as a fundamental aspect of space, in that not only does it close the space from an "outside" giving it a more "real" and concretized spatial character, it also constructs an inner cohesiveness that is subject to its own localized regulations. ${ }^{31}$

In other words, the compression of objects within the map's confines homogenizes them. The result is that the map normalizes the relationships between people and places. More simply, the map becomes the stand-in for the real place.

The Cholula pintura (painting or drawing) illustrates the difficulties of distinguishing the realities of the actual location from the abstract ideas about the place presented in the map. ${ }^{32}$ The Cholula cartograph brings to light the fallacies of European claims and ideas about the Americas and Indigenous peoples. For instance, it fails to convey the reality of the township's topography: the hills on the map are actually the remnants of larger earthen Pre-Columbian mounds that do not conform to the rigid European grid. Although the image presents a conceptualized implementation of European order on the city, vestiges of the town's pre-contact past are a reminder of another equally complex ideological narrative.

The emphasis on the relational value of the grid presents only one side of the cartographic spectrum. Indeed, the gridded map is just one form of cartographic imagery. Other, more popular forms include itinerary maps-cartographs that sacrifice longitudinal and latitudinal accuracy in favour of rela-

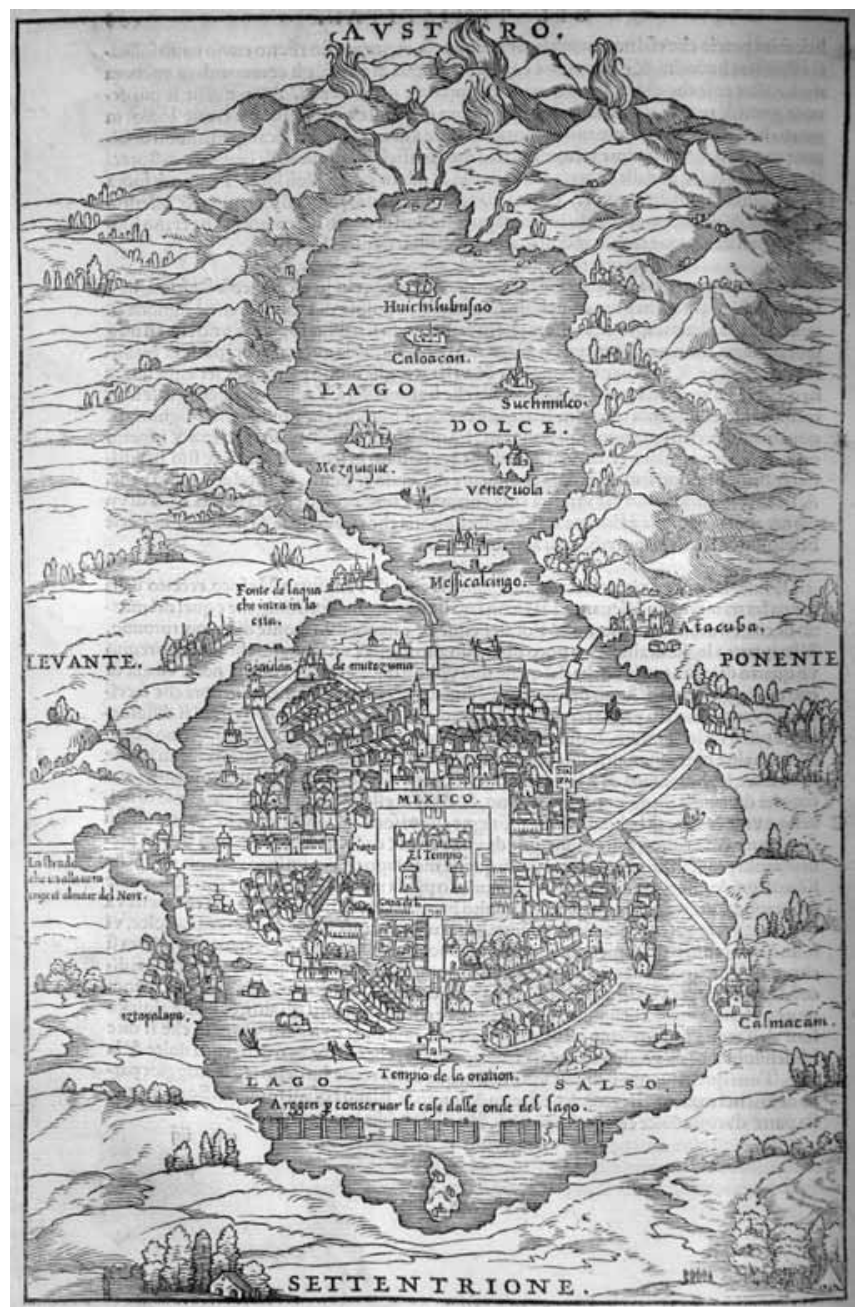

Figure 4. Giovanni Battista Ramusio, II Mexico Citta. From Viaggi et Navegatinoi, vol. III (Venice, I556). Engraving, height: $33 \mathrm{~cm}$ (photo courtesy of The University of Western Ontario Libraries, London, Ontario).

tional connections between geographies and towns, as in the Motul image (fig. 1). The images offer differing narratives and constructs about space, ones that contradict the rigidity of the grid and oppose the perceptions that the Spanish monarchy and European intellectuals attempted to develop about America. Indeed, the images offer the perspectives of those living in Hispanic America.

\section{The Map's Other History}

Like the Motul image, the Cholula map offers another layer of complexity regarding sixteenth-century mapmaking practices: many of the works were produced by Indigenous artisans, not European cartographers. Some maps indicate an astounding 


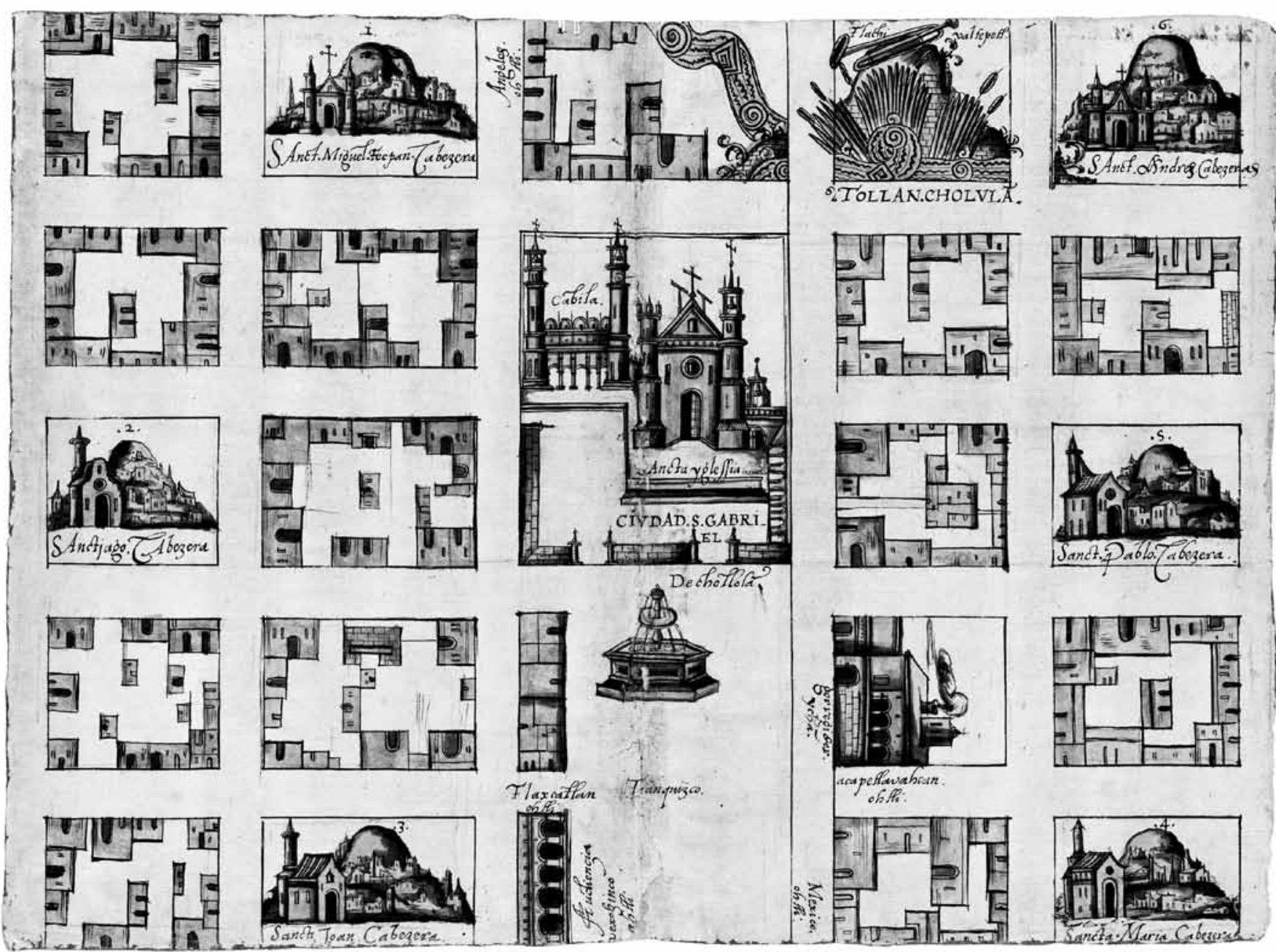

Figure 5. Anonymous, Map of Cholula (Puebla), 158I. Coloured ink on paper, $31 \times 44 \mathrm{~cm}$. Austin, Nettie Lee Benson Latin American Collection (artwork in the public domain; photo courtesy of the University of Texas Libraries, The University of Texas at Austin).

level of hybridization of distinctive artistic and intellectual practices. This is the case of the Cholula pintura, where the Mixtec artist comfortably bridges the cultural divide. Such syncretism was made possible by the training many Indigenous noblemen received at the convento (convent) schools, 33 which enabled Native American artists and intellectuals to produce powerful multivocal objects and treatises. One example is the illustrated text El primer nueva corónica y buen gobierno (The First New Chronicle and Good Government) created by the Quechua nobleman Felipe Guaman Poma de Ayala in 1615. This work, which presented an Andean history as told by Poma to King Philip III, was anomalous in its size, scope, and scale.

Other works, including the relaciones images, were collaborative projects involving Indigenous artists and scribes as well as Spanish court officials. Art historian Barbara Mundy has documented the intellectual exchange that occurred between Mixtec and Europeans artists in a group of geographic accounts known today as the Relaciones Geograficas of Central Mexico. ${ }^{34}$ Mundy argues that the content of many images presents a startling contrast to European-crafted maps. The differences are explicit in the map of Teozacoalco (San Tedro Teozacoalco), Oaxaca (fig. 6). This Indigenous image is the embodiment of Pre-Columbian "mapping" practices; its circular composition can be equated to Mesoamerican cosmology and calendrical systems. 35 The image conforms to Mixtec practices of recording histories through glyphic and pictographic forms: the dynasties that dominated the political culture of the Teozacoalco territory years before the arrival of the conquistadores are presented in the left hand margin. Moreover, the work indicates Indigenous territorial expansions with the inclusion of 


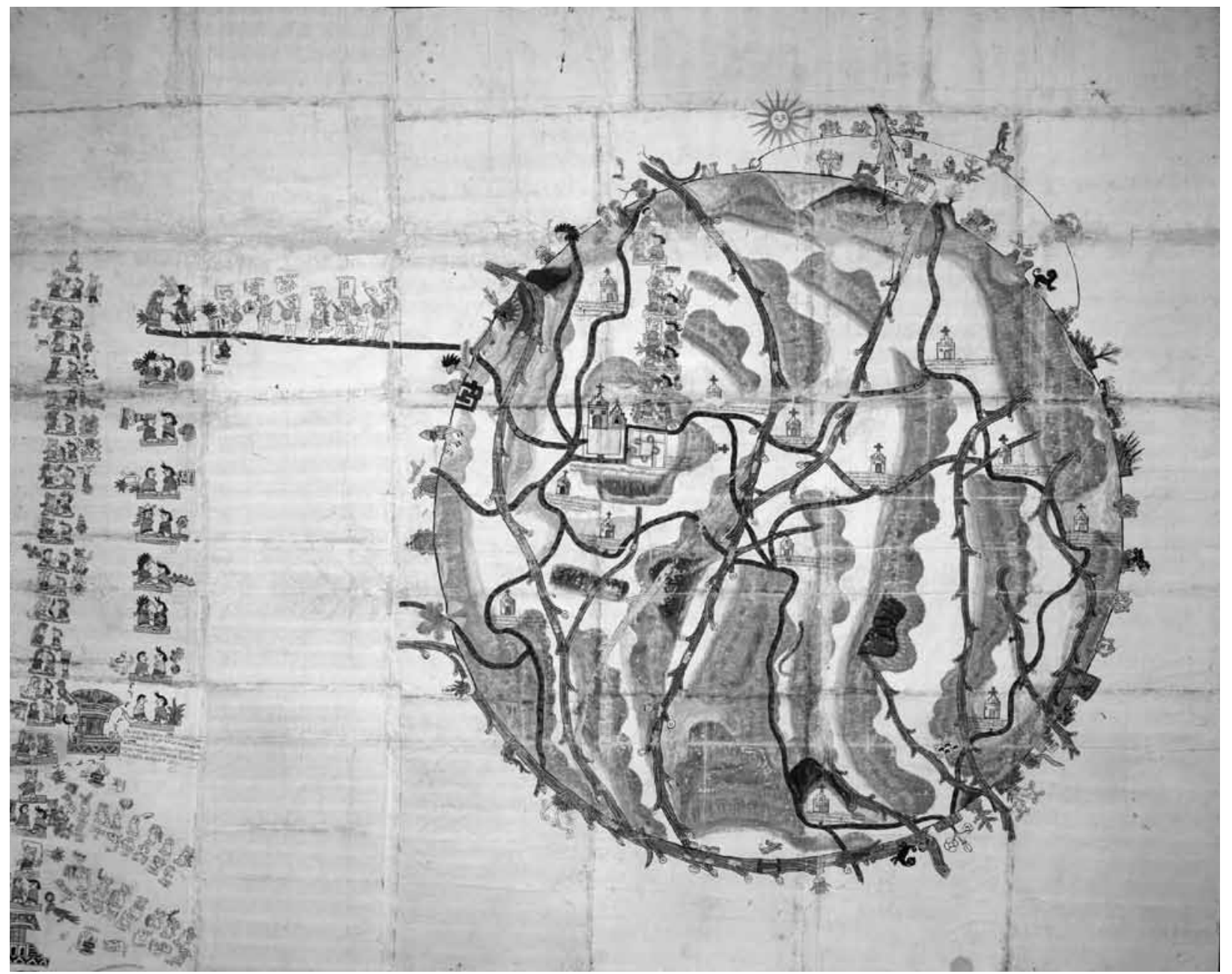

Figure 6. Anonymous, Map of Teozacoalco (San Tedro Teozacoalco, Oaxaca), 1580. Coloured ink on paper, $138 \times 176 \mathrm{~cm}$. Austin, Nettie Lee Benson Latin American Collection (artwork in the public domain; courtesy of the University of Texas Libraries, The University of Texas at Austin).

a newly annexed territory in the upper zone of the circular map. The expanded lands and Indigenous attire of the ruling couples assert the Mixtec relationship to the principal map's geography, with its mountains and rivers. The Christian convents, with their identifying Spanish texts, are virtually lost in the Mixtec world.

The Yucatecan map of Tabasco, called the "Alfaro Map," presents a similarly complex Indigenous world, barely populated by Christian missions (fig. 7). Named after Melchor Alfaro de Santa Cruz, the Spanish estate holder charged with documenting the land, it is another example of a hybrid image, this one likely co-produced by a Chontal Maya artist. ${ }^{36}$ The Alfaro Map, like the Motul drawing, privileges the eastern direction-as was standard in Maya practice-as can be established by the trees, churches, and mountains. The image's accompanying Spanish writing, probably executed by Alfaro himself, has no single orientation, though it does appear to privilege the north through accented compass marks. This is to be expected, as instruction number 10 from the relaciones geográficas advises,

\footnotetext{
Describe the site and state the situation of said town, if it lies high or low or in a plain, and give a plan or colored painting showing the streets, squares, and other places; mark the monasteries. This can be easily sketched on paper, and shall be done as well as possible. It is to be noted which part of the town face North and which South. 37
}

The image's conflation of European and Mesoamerican cartographic traditions exposes the contradictions in Hispanic American mapping practices. The Motul map, though much 




Figure 7. Anonymous, Map of Tabasco (Mexico), 1579. Coloured ink on paper, $60 \times 57 \mathrm{~cm}$. Seville, Archivo General de Indias (photo courtesy of Archivo General de Indias).

more simply drawn, is similarly complex. While the rendering of the church indicates an eastern direction, the map has multiple viewing perspectives, and is oriented by Motul's church from which the colonial pathways and roads radiate. This fractured compositional design, or organization, marks a radical departure from Bleau's systematized world. In both the
Alfaro Map and the Motul drawing, the compositions are organic and lack precise orientating tools. The cartographs adopt more popular "itinerary map" designs found in Western and Mesoamerican traditions.

Often itinerary maps were drafted to visualize the proximity between locations. In so doing, the mapmakers frequently 
BARTEET | Contested Ideologies of Space in Hispanic American Cartographic Practices

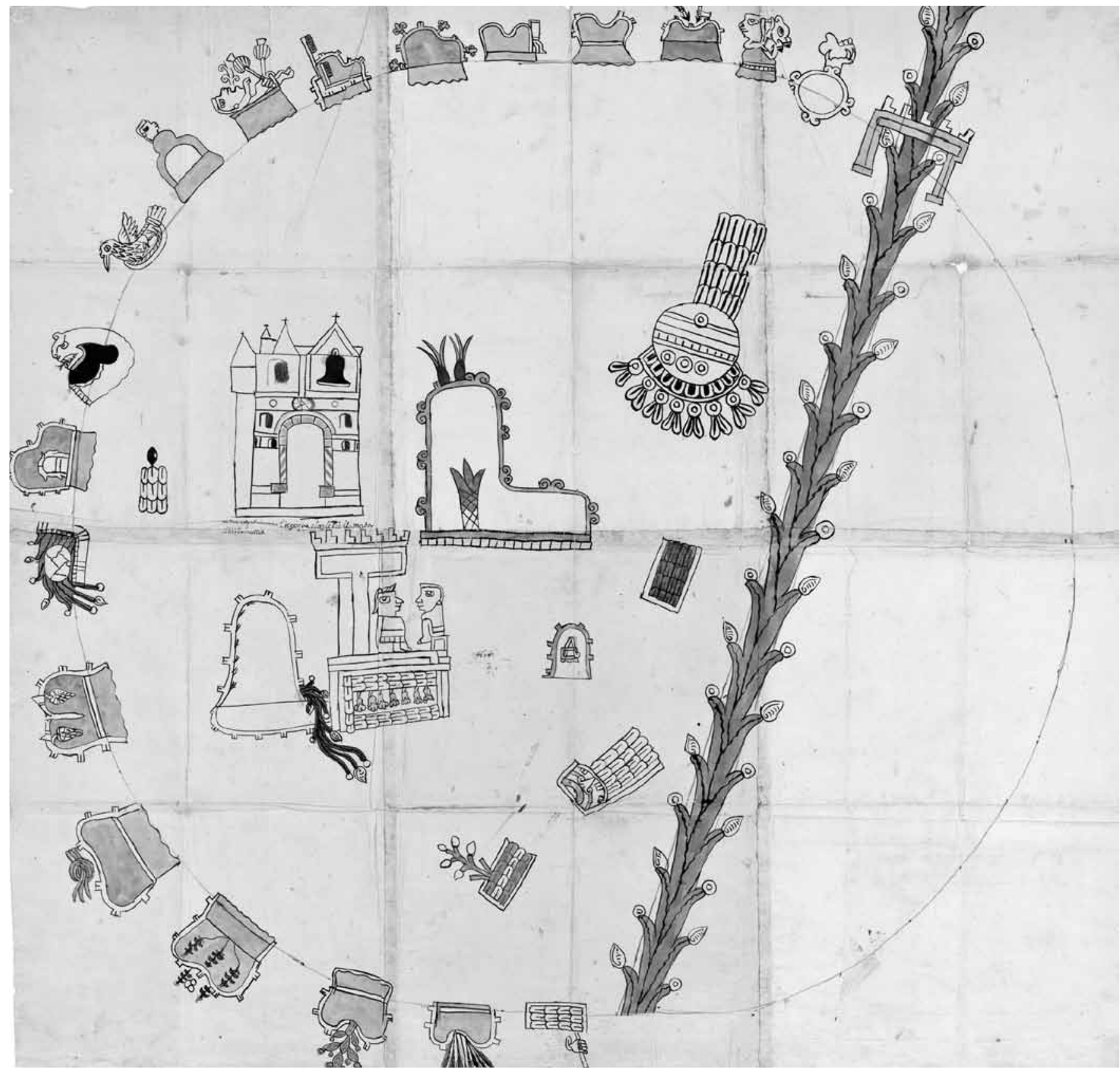

Figure 8. Anonymous, Map of Amoltepec (Mexico), 1580. Coloured ink on paper, $86 \times 92 \mathrm{~cm}$. Austin, Nettie Lee Benson Latin American Collection (artwork in the public domain; photo courtesy of the University of Texas Libraries, The University of Texas at Austin).

sacrificed specificity of topography, culture, and scale. The Motul drawing epitomizes the itinerary tradition as it shows the routes that connect Motul to its tributaries and to Mérida. The map, however, lacks references to topography or scale. Similarly, the Alfaro Map forfeits the relational scale between convents and communities in favour of an astoundingly rich portrayal of the Tabascan landscape. Curiously, the vast openness of the image unsettled Alfaro, who obsessively scribbled within the margins, providing a great deal of information about the various areas of the province as if to compensate for the map's lack of scale and quantifiable data. The Alfaro Map is, however, anomalous within the relaciones geográficas. 


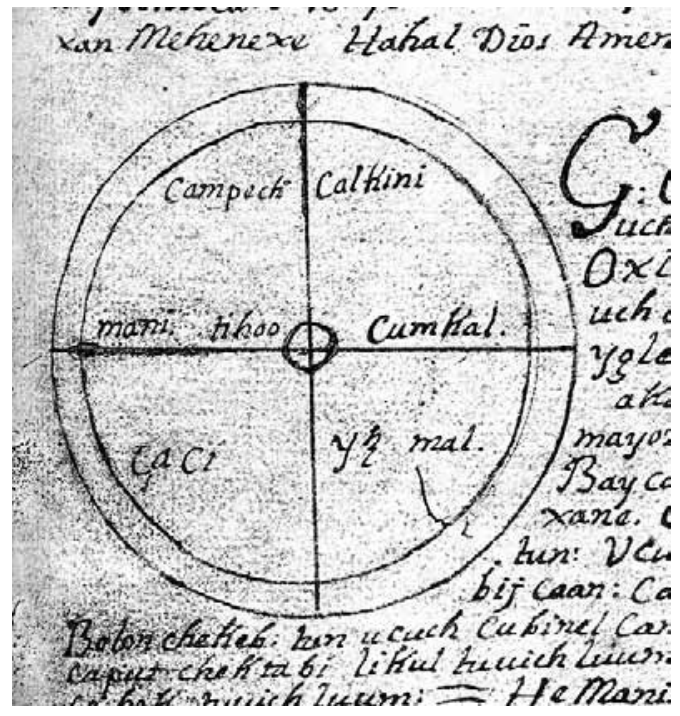

Figure 9. Anonymous, "Bird Map." From Chilam Balam of Chumayel eighteenth century. Ink on paper, full page $20 \times 15 \mathrm{~cm}$. Rare Books and Special Collections, Princeton University Library (artwork in the public domain; Princeton University).

The impact of the Motul drawing, the Teozacoalco image, and the Alfaro Map on sixteenth-century cartography_or even on Spanish claims to the Mexican territories-is difficult to ascertain. After all, the circular mappae mundi were frequently found in European courts before their popularity waned with the publication of Ptolemy's Geography at the end of the fifteenth century. ${ }^{38}$ Moreover, these three works are among the few examples of circular maps in the relaciones geograficas, the fourth being the coloured map of Amoltepec (fig. 8). Yet a tradition of circular maps persisted in Yucatán well into the colonial era, from which at least eight cartographic-like objects survive: the Alfaro Map, the so-called Bird Map of the Chilam Balam of Chumayel (ca. eighteenth century), three treaty maps of the provinces of Mani (1557), the Sotuta (based on a now lost sixteenth-century map), the Acanech (ca. sixteenth-century), and the seventeenth-century "Rosa de Vientos" murals at Motul.39

There are some common features among the works (including those not reproduced here), which can be seen in the Alfaro Map, the Bird Map (fig. 9), and the Mani Treaty Map (fig. 10). All the images are circular in composition; all use a double ring border that creates a band; and all apart from the Bird Map have data recorded within the band that identifies towns and boundaries, while the Motul work contains temporal information pertaining to the calendar. ${ }^{40}$ The circular composition, also found in the Teozacoalco map, is reminiscent of the coordinating rings of the European compass rose. In fact, the Bird Map is astoundingly similar to the compass design, clearly indicating a blending of traditions. It is a highly abstract circular cartograph segmented by a cross shape, which is nestled within the pages of the eighteenth-century book of the chilam balam of the Maya town of Chumayel. The image created by an anonymous Maya artist reconstructs the political geography of Yucatán. ${ }^{41}$ The image's name derives from its accompanying text, which references the various centres through the analogy of the bird:

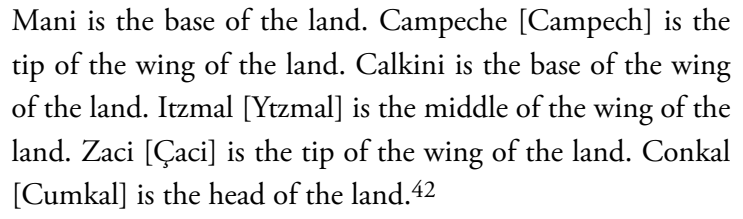

At the centre of the bird is Tihoo (more commonly spelled Tihó, now Mérida), which in the following line is identified as the spiritual capital of Yucatán. Interestingly, the capital is not discussed within the map's composition. Presumably, the artist assumed that his Maya audience would recognize it as the peninsula's political and religious capital and felt that it was not necessary to identify it in the text.

Nonetheless, the Bird Map questions the political and spiritual significance of Mérida: the capital is referenced by its Maya name, as are the important Spanish centres of Campeche (Campech) and Valladolid (Zaci). Moreover, the Maya town of Mani is privileged over all others. Described as "the base of the land [or the peninsula]," Mani is given extreme prestige as a place of origin, in this instance as the place of origin of the whole peninsula. The author's concerns seem to relate more closely to a Maya audience than to a Spanish one. Considering the chilam balam are rife with communal and clan efforts at self-representation, these inclinations are not surprising. Indeed, Chumayel was a direct tributary of Mani, and its rulers were members of the Xiu family clan that ruled Mani; it was politically, socially, and culturally wed to the Maya capital. Thus, the image honours a pre-contact Maya past well into the colonial era.

Such references can also be found in the relaciones geograficas, for the instrucciones specifically requested communal histories. The Teozacoalco image, for example, presents a history of the land's occupation that long predates Spanish claims to the territory. In both the Teozacoalco and Cholula maps, the legacies of the groups' Pre-Columbian pasts are apparent, whether through spatial realizations, compositional designs, decorations, or bilingual scripts. Such features hint at a contestation of Spanish authority. Simply put, the works' Indigenous content and histories question the colonial assertion of the newness of the New World. In fact, the cartographs affirm that the New World was not new and that the spaces of the continents had already been produced by Indigenous cultures. Indeed, the Map of Teozacoalco records the province's lineage in order to 




Figure 10. Gaspar Antonio Chi, attributed, The Mani Land Treaty Map, 1557. European brown ink on European paper, $41 \times 31 \mathrm{~cm}$. The Latin American Library, Tulane University, New Orleans (artwork in the public domain; courtesy of the Latin American Library, Tulane University). 


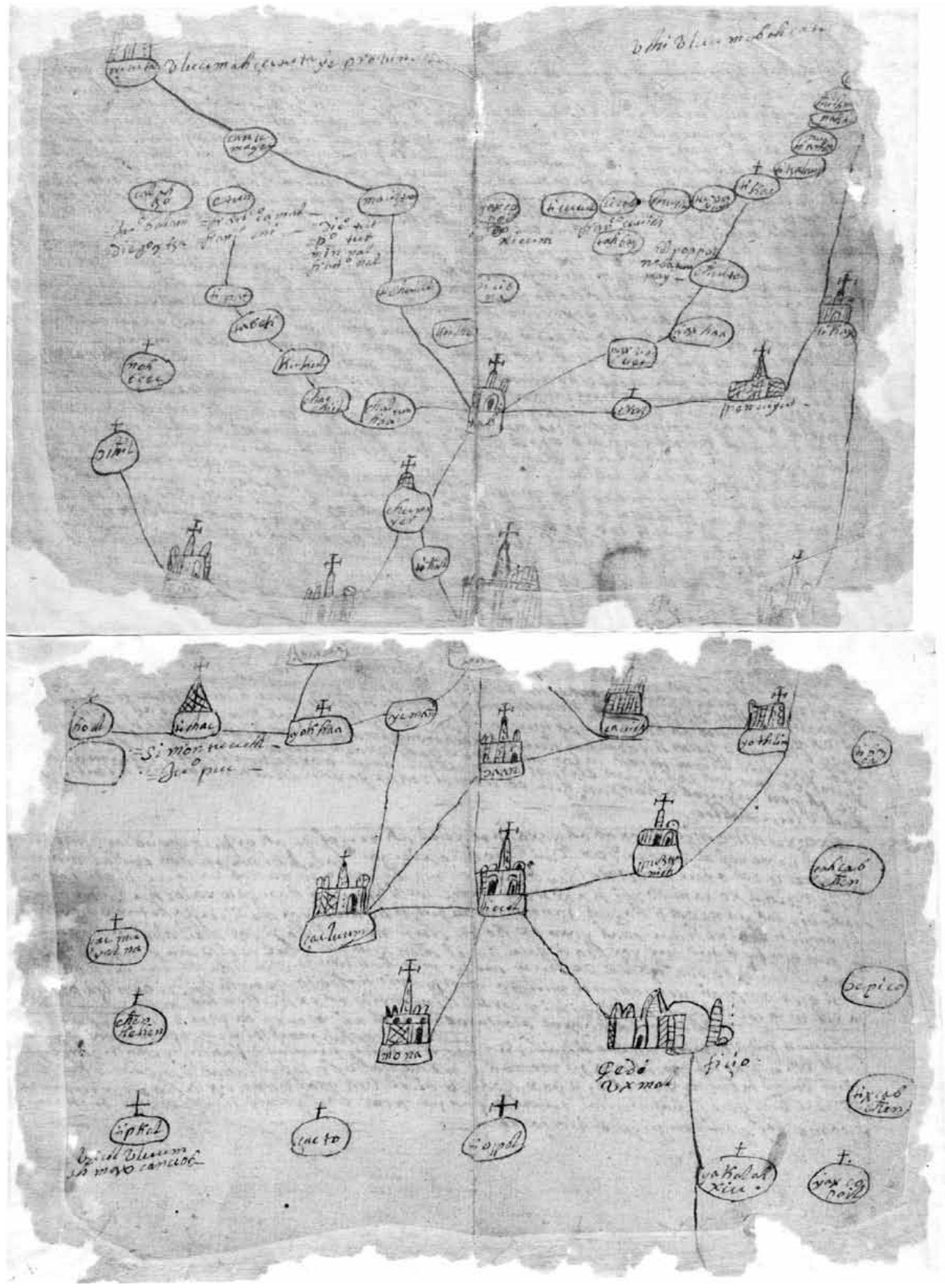

Figure II. Anonymous (Gaspar Antonio Chi?), The Map of Mani, ca. I560. From The Xiu Chronicles. Ink on paper, $41 \times 31 \mathrm{~cm}$. Tozzer Library Special Collections, Harvard University, Cambridge, MA (artwork in the public domain; courtesy of Tozzer Library, Harvard University). 
affirm the ruling family's pre-contact authority and to assist in securing its position in the colonial era.

Similarly, the sixteenth to nineteenth-century documents known as the Xiu Chronicles record the Xiu Maya clan's claims on the town of Mani and its environs. 43 The Xiu texts were drafted for different purposes than the relaciones geográficas: they are a probanza de hidalguia (proof of nobility) given to the local colonial administrators, presumably so that the crown could grant Xiu familial claims of nobility and sovereignty over the Mani polity. In so doing, the documents affirmed the Xiu lord's statuses as señores naturales (natural lords). Such a status was important in Yucatán as it secured lineage succession and afforded prestige to the Maya lords: they were exempt from some Spanish tribute demands and were also allowed to collect tribute from the local peasants of their communities. ${ }^{44}$ Thus, the papers are examples of communal self-representation, evincing the Xiu's efforts to maintain their Pre-Columbian status in the colonial era against the Spanish as well as against rival Maya clans. 45

La Memoria de la distribución de los montes de Mani a 15 de agosto de 1557 (The Report of the Distribution of the Lands of Mani, 15 August 1557) is one of these documents within the Xiu Chroncles. ${ }^{46}$ It describes the boundaries of the Xiu polity as they were defined through a land agreement with rival Maya chibalob (lineages) in accord with the Spanish colonial administration. In so doing, La Memoria illustrates a hybrid idea of the Yucatecan province as it combines Maya and Spanish understandings of space. To make the land treaty more accessible to all colonial audiences, i.e., Maya and European, it was translated into at least two maps: the drawing that accompanies the Xiu Chronicles (fig. 11) and another version that accompanies colonial administrative papers in Tulane University's Latin American Library (fig. 10). ${ }^{47}$

The two maps of Mani record the information contained in the 1557 land treaty in similar ways: they represent the Xiu polity and illustrate the interrelationships between towns. Both images adopt a quasi-itinerary format, situating Mani as the territory's principal town with tributary influence extending over a large populated area with numerous townships. However, the works served different purposes. The Map of Mani (fig. 11) was developed to accompany the documents that argued for nobility, while the Mani Land Treaty Map (fig. 10) was likely produced for colonial administrators to record the boundaries of the Mani province as established by the treaty of 1557 . The latter uses a circular composition to depict the Xiu lineage and territories. As art historian Amara Solari has suggested, the circular drawing presents a new cartographic form that combines Maya and Spanish mapping traditions in an idealized representation with an Indigenous sensibility in narrative and format. ${ }^{48}$ The image is also informative, as it indicates Maya attempts to main- tain pre-contact polity lines into the colonial era. The treaty map does this through its design, which assists in facilitating Xiu historical claims to the territory. Thus, the towns recorded within the border and in its frame are those over which the Xiu of Mani held direct political sway, while those beyond are tertiary towns.

Objects like the Mani maps and the Bird Map work to produce space. They are visual productions of communal selfrepresentation that indicate Maya efforts to maintain precontact agency and autonomy in the colonial era. The colonial Xiu's appropriation of foreign media and cultural practices into their own Maya traditions ultimately created a new space or form of knowledge. The circular Mani map is a clear example of such creation that lends itself to multivocal readings by their Maya and European contemporaries.

Such claims and historical differences were frequently mitigated through the popular administrative judicial discourse and the othering of Indigenous peoples. Racial fetishization was rampant and can be seen in innumerable maps-for instance Blaeu's Americe Nova Tabula (see fig. 2) —as well as prints and texts that fostered racially explicit attitudes about Native Americans. These are also present in Jan van Doet's 1585 map of South America (fig. 12). ${ }^{49}$ In this image, many of the pejorative tropes about Indigenous peoples are replicated, sentiments further exacerbated by the similar taxonomic recordings of the peoples and animals in the map. In the royal instrucciones, seven questions were specifically related to the Indigenous peoples and their histories. 50 These questions serve to apprehend the Indigenous past from a Spanish perspective as well as through the Iberian language. Such exercises in "natural history," which recall the cuadros de castas, assist in further disenfranchising the Indigenous peoples by forcing them to operate within a new mode of language and within the power dynamics of the colonial administration. Nevertheless, many of the maps discussed here are multivocal, collapsing multiple systems of knowledge into one coherent document that narrates the histories of these regions. Despite their pronounced Mesoamerican heritages, the images were vital to the Iberians' efforts to claim and document the "unknown" American territories.

\section{Conclusion}

The Motul image (fig. 1) uses the itinerary map format to quickly and effectively document the connections between Motul, its affiliate townships, and the provincial capital, all urban locations identified by hybridized religious structures. The work thus illustrates people's migration through these spaces, demonstrating that travel and exchange occurred through prescribed routes between the towns, without the use of bypasses. 


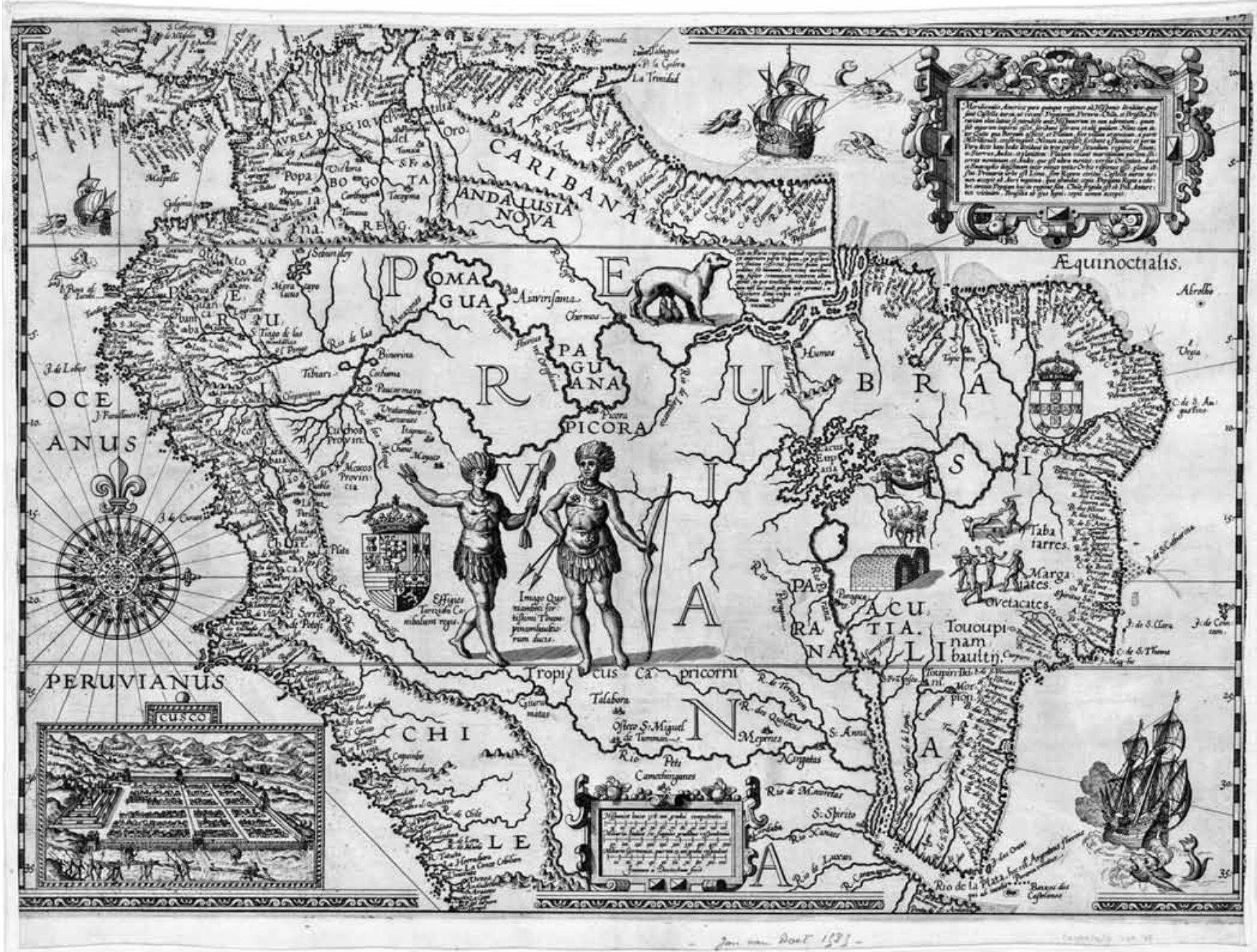

Figure 12. Jan van Doet, Meridionalis Americæ pars quinque regions ab Hispanis dividitur, 1585. Engraving, $55 \times 40 \mathrm{~cm}$. Austin, Nettie Lee Benson Latin American Collection (artwork in the public domain; photo courtesy of the University of Texas Libraries, The University of Texas at Austin).

The creator of the image places Motul within the larger political and cultural networks of Yucatán. The map conveys Motul's importance- despite the fact it was considered subordinate to Mérida-identifying its political, economic, judicial, and religious influence over other towns. Situating Motul as a "secondary" Yucatecan centre with sway over a locality, the drawing replicates the flow of information in the province. Information arrives in Mérida from the royal and viceregal courts; it is, in turn, directed to the local polities, like Motul; from Motul it is further filtered to its townships-or vice versa in a reverse sequence of steps. The image therefore not only documents the land, albeit in conceptual terms, it replicates the way information is transmitted through the centres and peripheries of the Hispanic world. In this manner, the map produces both space and structures of power. At the same time, the Motul image serves to define township lines and polity centrism against rival Maya claims.

Even though they had to fulfill the bureaucratic instructions of the relaciones geograficas, the Motul and other maps studied here retain their Mayaness. They do so through their orientation, multiple viewing perspectives, and representation of time and space; and clearly they honour the pre-contact Maya past. Although attempts were made to mitigate Indigenous territorial claims, as in the maps of the relaciones geográficas, the peoples that occupied the American spaces continuously contested these assertions. The maps they produced illustrate the colonial encounter and the abstractions of cartography through the visual presentation of history's counternarratives. 
Notes

1 The Spanish monarchs entrusted the Casa de Contratación (House of Trade, founded in 1503) to carry out much of the task of documenting the empire.

2 Barbara Mundy has identified that forty five (or $65 \%$ ) of the sixtynine images of New Spain were drawn by Indigenous artists. For more information see Mundy, The Mapping of New Spain: Indigenous Cartography and the Maps of the Relaciones Geograficas (Chicago and London, 1996).

3 For discussions of the relaciones geográficas, see Barbara Mundy, The Mapping of New Spain; Mundy, "Hybrid Space," in Mapping Latin America: A Cartographic Reader, eds. Jordana Dym and Karl Offen (Chicago and London, 2011), 51-55; Howard F. Cline, "The Relaciones Geográficas of the Spanish Indies, 1577-1586," The Hispanic American Historical Review 44, 3 (August 1964), 341-74. For translations of the instructions, see Cline, "The Relaciones Geográficas" and Mundy, The Mapping of New Spain.

Likewise, the Nettie Lee Benson Latin American Collection at the University of Texas, Austin, created a virtual exhibit of eleven of the relaciones geográficas. For more information, see http://www.lib. utexas.edu/benson/rg/. Additionally, digital copies of the original questions and their responses can be found online through Spain's Ministerio de Educación, Cultura y Deporte's PARES (Portal de Archivos Españoles). See Archivo General de Indias (AGI), Indiferente General, Descripción de los pueblos de Yucatán, 1530, n. 5.

4 For the copyrighted digital reproduction of the document (map and text), see PARES, AGI, Mapas y Planos, México, 30, Plano del pueblo de Mutul [sic.], en la Provincia de Yucatan, términos de la Ciudad de Mérida, 1581, and AGI, Indiferente General, Descripción de los pueblos de Yucatán, 1530, n. 5.

5 I will return to these points later in the paper.

6 The books of the chilam balam, which are sometimes referenced as Mesoamerican primordial titles, are compilations of the shorter títulos and crónicas (annals). Títulos are municipal texts that record the community's history as well as information used to promote the community's interests. The crónicas are shorter community histories that contain similar information, including specifics on important events, the participants involved in them, and the effects of these events on the community.

7 Francisco Estrada-Belli and Heather Hurst, "Palace Arts," in Mapping Latin America: A Cartographic Reader, eds. Jordana Dym and Karl Offen (Chicago and London, 2011), 25-28.

8 For a review of the popularity of Indigenous maps in Yucatán, see Michel Antochiw, Historia cartográfica de la Peninsula de Yucatán (Campeche, 1994) and Amara Solari, The Transfiguration of Space: Maya Ideologies of the Sacred in Colonial Yucatan (Austin: University of Texas Press, 2013).

9 Although not discussed here, Hispanic America should not simply be contextualized in a transatlantic setting; important trade routes extended to Asia, thus establishing a transpacific context as well.

10 Henri Lefebvre, The Production of Space, trans. Donald NicholsonSmith (Cambridge, 1991).

11 Ricardo Padrón has argued that Spanish mapping practices did not keep pace with the numerous scientific and mathematical developments occurring in other European territories, and were therefore not widely adopted. Conversely, María Portuondo has suggested that Spanish maps were not as widely reproduced because of the monarchy's attempt to maintain control of cosmographic and cartographic data. Much of this data was codified over the years of production as the international cartographic practitioners employed by the Spanish crown developed certain sets of expected information to be presented on Iberian maps.

For more information on these various concepts see Edward Collins, "Francisco Faleiro and Scientific Methodology at the Casa de la Contratación in the Sixteenth Century," Imago Mundi: The International Journal for the History of Cartography 65, 1 (2013), 25-36; Ricardo Padrón, "Mapping Plus Ultra: Cartography, Space, and Hispanic Modernity," Representations 79 (Summer 2002), 28-60; María Portuondo, Secret Science: Spanish Cosmography and the New World (Chicago, 2009); and David Turnbull "Cartography and Science in Early Modern Europe: Mapping the Construction of Knowledge Spaces," Imago Mundi: The International Journal for the History of Cartography 48, 1 (1996), 5-24.

Aside from his insightful article, Padrón offers a more thorough and compelling study of Spanish cartographic practices in relationship to the roots of modernity in The Spacious Word: Cartography, Literature, and Empire in Early Modern Spain (Chicago, 2004).

12 J. B. Harley, The New Nature of Maps: Essays in the History of Cartography, ed. Paul Laxton (Baltimore, 2001), 278.

13 Jordana Dym and Karl Offen have edited a compilation that presents the latest and most nuanced studies of colonial Latin American maps. For more information, see Dym and Offen, eds., Mapping Latin America. Raymond B. Craib's earlier study of maps also offers a valuable overview. See Craib, "Cartography and Power in the Conquest and Creation of New Spain," Latin American Research Review 35, 1 (2000), 7-36.

14 Walter Mignolo, The Darker Side of the Renaissance: Literacy, Territoriality, and Colonization (Ann Arbor, 1995), 219-58; Woodward, "Maps and the Rationalization of Geographic Space, in Circa 1542: Art in the Age of Exploration, ed. Jay A. Levenson (New Haven, 1991), 83-87; and Harley, The New Nature of Maps.

15 The castas have been discussed with increased scholarly interest in the past decades. See Magali M. Carrera, Imagining Identity in New Spain: Race, Lineage, and the Colonial Body in Portraiture and Casta Paintings (Austin, 2003); Carrera, "Creole Landscapes," in Mapping Latin America, eds. Dym and Offen, 110-13; Ilona Katzew, Casta Painting: Images of Race in Eighteenth-Century Mexico (New Haven, 2004); and Susan Kellogg, "Depicting Mestizaje: 
Gendered Images of Ethnorace in Colonial Mexican Texts," Journal of Women's History 12, 3 (Autumn 2000), 69-92.

16 See Mignolo, The Darker Side, 219-58, and Padrón, "Mapping Plus Ultra," 31.

17 This image reflects multiple European interests and not simply Spanish, as the work is not tied to a royal commission. Nevertheless, its sentiments are rooted in Spanish cartographic exercises, many of which served as the basis for the print.

18 Jean Baudrillard, Simulacra and Simulation, trans. Sheila Faria Glaser (Ann Arbor, 1994), 1.

19 For more information see Mignolo, The Darker Side, 219-58.

20 Richard Kagan, Urban Images of the Hispanic World, 1493-1793 (New Haven and London, 2000).

21 Kagan, Urban Images, 98-99.

22 AGI, México 359, r.6, n.28, f.1, Cartas de Gobernadores, Francisco de Solis, Junio 9, 1584.

23 An astoundingly productive and insightful body of scholarship exists relating to understanding and interpreting the origins, evolution, and application of the urban policies, and the actual cities themselves. Therefore I am only listing a selected bibliography relating to the subject, which includes both canonical texts as well as new studies: Allan Brewer-Carías, ed., La ciudad ordenada (Caracas, 2006); Dora P. Crouch, Daniel J. Garr, and Axel I. Mundigo, Spanish City Planning in North America (Cambridge, 1982); Graziano Gasparini, "The Laws of the Indies: The SpanishAmerican Grid Plan, the Urban Bureaucratic Form," The New City 1 (Fall 1991), 6-33; Lucía Mier y Terán Rocha, La primera traza de la Ciudad de México, 1524-1535, 2 vol. (Mexico City, 2005); Paul Rabinow, "Ordinance, Discipline, Regulation: Some Reflections of Urbanism," Humanities in Society 5, 3-4 (Summer and Fall 1982), 267-78; and Jaime Salcedo, Urbanismo HispanoAmericano, Siglos XVI, XVII y XVIII: El modelo urbano aplicado a la América española, su génesis y su desarrollo teórico y práctico, 2nd ed. (Santa Fe de Bogotá, 1996).

24 Lefebvre, The Production of Space, 161.

25 Kagan, Urban Images, 98-99.

26 For a recent discussion of the Cholula image, see Mundy, "Hybrid Space."

27 Although the Aztecs are the most widely known cultural group in Mexico, many others were present at contact, including the Mixtecs, who inhabited the present day Mexican states of Oaxaca, Guerrero, and Puebla.

28 Dana Leibsohn, "Primers for Memory: Cartographic Histories and Nahua Identity," in Writing without Words, eds. Elizabeth Boone and Walter D. Mignolo (Durham, 1996), 161-87; Leibsohn, "Colony and Cartography: Shifting Signs on Indigenous Maps of New Spain," in Reframing the Renaissance, ed. Claire Farago (New Haven, 1995), 271, 273, 278.

29 For discussions of the significance of churches as social markers, see Kagan, Urban Images, 61, and Kagan, "Urbs and Civitas in Six- teenth- and Seventeenth-Century Spain," in Envisioning the City: Six Studies in Urban Cartography, ed. David Buisseret (Chicago, 1998), 17-108.

30 See the following sources for more information relating to the blending of word and image: Tom Cummins and Joanne Rappaport, "The Reconfiguration of Civic and Sacred Space: Architecture, Image, and Writing in the Colonial Northern Andes," Latin American Literary Review 26, 52 (July-December 1998), 174-200; Alan Durston, "Un régimen urbanístico en la América hispana colonial: El trazado de damero durante los siglos XVI y XVII," Historia 28 (1994), 55-115; Jesús Escobar, "Toward an Urbanismo Austríaco: An Examination of Sources for Urban Planning in the Spanish Habsburg World," in Early Modern Urbanism and the Grid: The Low Countries in International Context. Exchange in Theory and Practice, 1550-1800, eds. Piet Lombaerde and Charles van den Heuvel (Turnhout, Belgium, 2011), 161-75; Escobar, The Plaza Mayor and the Shaping of Baroque Madrid (Cambridge, 2003); and Michael Schreffler, The Art of Allegiance: Visual Culture and Imperial Power in Baroque New Spain (University Park, PA, 2007).

31 George Simmel as quoted in Andrze J. Zieleniec, Space and Social Theory (Los Angeles, London, New Delhi, Singapore, 2007), 42.

Numerous philosophers have consider the relationship between signs and symbols and their ideological purposes including Louis Althusser, "Ideology and Ideological State Apparatuses (Notes Towards an Investigation)" [1970], in Visual Culture: The Reader, eds. Jessica Evans and Stuart Hall, (London, 1999), 317-23; Roland Barthes, Image Music Text, trans. Stephen Heath (New York, 1977); and Immanuel Kant, The Critique of Judgment, tans. J. H. Bernard (New York, 2000).

32 Although typically considered maps, some of the cartographs of the relaciones geograficas are referred to as pinturas. See Donald Robertson, "The Pinturas (Maps) of the Relaciones Geográficas," in Handbook of Middle American Indians, vol. 12, Guide to Ethnohistorical Sources, ed. H. F. Cline (Austin, 1972), Part 1, 243-78.

33 Mundy, The Mapping of New Spain.

34 Although the Motul and Cholula images are both technically relaciones geográficas, capitalization has been used to distinguish between cartographs such as the Motul drawing that are part of the Relaciones de Yucatán and the Cholula, which is in the Relaciones Geográficas.

35 Mundy has discussed the interrelationships between the Mesoamerican calendar and the Relaciones Geográficas images. See Mundy, The Mapping of New Spain. Other scholars who have referenced the relationship between circular cartographic imagery and the Mesoamerican calendar system include Ralph L. Roys, The Indian Background of Colonial Yucatan (Washington, DC, 1943) and Amara L. Solari, "Circles of Creation: The Invention of Maya Cartography in Early Colonial Yucatán,” Art Bulletin 92, 3 (September 2010), 154-68. 
36 For discussions of the Alfaro Map, see Amara L. Solari, "Maya Spatial Biographies in Communal Memory and Cosmic Time: The Franciscan Evangelical Campaign of Itzmal, Yukatan" (PhD diss., University of California at Santa Barbara, 2007), 129-30; Solari, "The Relación Geográfica Map of Tabasco: Hybrid Cartography and Integrative Knowledge Systems in Sixteenth-Century New Spain," Terrae Incognitae: The Journal of the Histories of Discoveries 41, 1 (2009), 38-58; and France V. Scholes and Ralph L. Roys, The Maya Chontal Indians of Acalan-Tixhcel (Washington, DC, 1948), 16.

The Chontal Maya were one of the many Maya clan groups active in Mesoamerica at the time of contact.

37 Translation from Cline, "The Relaciones Geográficas," 366. Italics are mine.

38 For examples and discussions, see Padrón, The Spacious Word, and Woodward, "Medieval Mappamundi," in The History of Cartography: Cartography in Prehistoric, Ancient, and Medieval Europe and the Mediterranean, eds. J. B. Harley and David Woodward (Chicago, 1987), vol. 1, 286-370.

39 Several of these works are poorly studied, either as a result of their seclusion in private collections or just simple scholarly neglect. In her Maya Ideologies of the Sacred: The Transfiguration of Space in Colonial Yucatan (Austin, 2013), art historian Amara Solari examines many of these maps as they pertain to Maya perceptions of their sacred spatial geographies.

40 The Alfaro Map has a half band because it is interrupted by the depiction of the Gulf of Mexico. In design the Tabascan image brings to mind the Amoltepec cartograph.

41 Solari provides a detailed discussion of the Bird Map as it relates to European and Maya artistic and textual practices. Solari, Maya Ideologies.

42 Translation of the original Maya passage from Ralph L. Roys, The Book of the Chilam Balam of Chumayel (Norman, OK, 1967), 126.

43 The major studies of the Xiu Chronicles are Sylvanus G. Morley and Ralph L. Roys, The Xiu Chronicle. Xiu Probanzas and Family Records, 2 vols. (Cambridge, MA, 1941); Sergio Quezada and Tsubasa Okoshi Harada, Papels de los Xiu de Yaxá, Yucatán (Mexico City, 2001). Recently Harvard Libraries have digitized the Xiu papers, which are available for consultation at http://pds.lib.harvard.edu/pds/view/1 0673001 ? $\mathrm{n}=1$ \&imagesize $=1200 \&$ jp2Res $=.125 \&$ print Thumbnails $=$ no. For art historical analyses of the Xiu images, see Constance Cortez, "Gaspar Antonio Chi and the Xiu Family Tree" (PhD diss., University of California, Los Angeles, 1996); Cortez, "New Dance, Old Xius: The 'Xiu Family Tree' and Maya Cultural Continuity after European Contact," in Heart of Creation: The Mesoamerican World and the Legacy of the Linda Schele, ed. Andrea Stone (Tuscaloosa and London, 2002), 201-15; and Solari, "Circles of Creation," 154-68. Most scholars, including those cited herein, suggest that the various artistic images within the Xiu Chronicles were created by the Maya nobleman and cleric, Gaspar Antonio Chi.
44 Within the Xiu papers, there are numerous instances where the sixteenth and seventeenth-century heads of the lineage attempted to invoke or retain these rights. This is most explicit in the 1641 probanza of Juan de Cimé, which argued that as "the as descendants of the naturals lords [of Mani], [he and his sisters] should enjoy what their parents, grandparents, and ancestors enjoyed, paying no tribute [to the Spanish] nor rendering personal services like plebeian Indians, rather, they [the plebeians] should serve them [the natural lords] and farm their fields." Juan de Castañeda (scribe), Probanza de don Juan, doña María y doña Petrona Xiu Cimé (1640-43) from The Xiu Chronicles, folios 17-18, Tozzer Library Special Collections, Harvard University, Cambridge, MA.

45 It is well documented that the Xiu were embroiled in numerous feuds with rival Maya clans, most notably the Cocom. For discussions of their contentious relationship, see Alfred M. Tozzer, ed. and trans., Landa's Relación de las cosas de Yucatán, in Papers of the Peabody Museum of American Archaeology and Ethnology, vol. 18 (Cambridge, MA, 1941).

46 For a Spanish transcription and translation of the Maya and Spanish language documents, see Sergio Quezada and Tsubasa Okoshi Harada, Papels de los Xiu de Yaxá, Yucatán (Mexico City, 2001), $55-56$.

47 Another copy of the map is found in John Lloyd Stephens's text. See Stephens Incidents of Travel in Yucatan, 2 vols. (New York, 1843), 2: 260-61.

48 Solari, "Circles of Creation," 154-68. In her insightful essay, Solari relates the circular map to the "Itza Invasion Episode" from the Book of the Chilam Balam of Chumayel. In the text, the story of the Itza occupation of Yucatán is told in a cyclical narrative (both conceptually and geographically) that recasts the Itza to the primordial beginnings of Yucatán's Pre-Columbian past.

49 Countless other Europeans likewise attempted to grasp understandings of the Americas and their peoples. The following examples show conflicting and changing views of Amerindians (and also hint at the tensions between international colonial powers): The Landing of Christopher Columbus, title page of Giulaino Dati's La lettera dell isole che ha trovatro nouvamente il Re di Spagna (1493, woodcut, British Library, London); The Peoples of the Islands Recently Discovered... (ca. 1505, woodcut with colour wash, Bayerische Staatsbibliothek, Munich); Theodor Galle (after Jan van der Straet), Vespuci Discovering America (1600, engraving, British Museum, London); Theodor de Bry, The Landing on Española (1594, engraving, British Museum, London); and John White, Village Section (1585, coloured engraving, Gilcrease Museum, Tulsa).

50 Questions 5 and 11-16 relate to the Indigenous peoples. See Cline, "The Relaciones Geográficas," 363-71, for a transcription and translation, or visit PARES online, AGI, Indiferente General, Descripción de los pueblos de Yucatán, 1530, n.5, which contains numerous copies of the questionnaire within the Yucatecan relaciones. 